\title{
Preliminary Phytochemical Screening of Seeds of Phytolacca Latbenia (Moq.) walte. A Wild Medicinal Plant of Tropical and Sub-Tropical Region of Pakistan
}

\author{
Shabir Ijaz*, Anjum Perveen, Nausheen Ghaffar \\ Centre for Plant Conservation, University of Karachi, Pakistan \\ Submission: October 10, 2019; Published: November 13, 2019 \\ *Corresponding author: Shabir Ijaz, Centre for Plant Conservation, University of Karachi, Pakistan
}

\begin{abstract}
Phytolacca latbenia (Moq.) walte locally known as Luber belonging to family Phytollacaceae is used in traditional medicine system and pharmaceutical industries as well. Whole plant is medicinally important. The aim of this study was to analyze the seeds of Phytolacca latbenia (Moq.) Walte physico-chemically and phytochemically. Various bioactive compounds (alkaloids, terpenoids, favonoids, saponins, carbohydrate, proteins etc) were detected in water extract, while other solvents were not ideal for extraction few compounds were screened out from them. High extraction was done by water solvent and low value was in acetone solvent. Seeds of Phytolacca latbenia showed variety of therapeutic potential due to the presence of several phytochemical compounds.
\end{abstract}

Keywords: Phytolacca latbenia; Phytochemical; Physicochemical screening; Seeds

\section{Introduction}

Bioactive compounds plants have been used for a long time in our history both as medicine and supplement to support normal physiological functions of the body. Many compounds are added for medicinal purposes when knowledge of their function finds out [1]. Several natural compounds have been assigned to herbs. These medicinally important herbs are the primary source of healthcare and pharmaceuticals products [2]. The story of the use of plants for a medicinal purpose is likely as old as the history of human being. Traditional uses of folk medicine provide key knowledge for the extraction and development of many drugs and activity as well [3]. Extraction and characterization of numbers of bioactive compounds from green factories are a reason to manufacture some highly active drugs [4]. Plant-based secondary metabolites play basic roles in human health and food source as well [5]. Phenolic compounds have biological properties such as anticarcinogen, Antiapoptosis, anti-aging, cardiovascular protection, anti-atherosclerosis, anti-inflammation, and improvement of the endothelial function [6].

The biologically crude drug is more effective than the isolated compound because of their synergistic effects [7]. For tracking of phytochemicals in plants, a plant is taken for screening to find out the presence of several chemicals including alkaloids, flavonoids, fixed oil, glycosides, and saponins, etc. The activity of secondary metabolites in plants as defense mechanisms against predation by many microorganisms, insects, and herbivores [8]. Herbal medicines are more beneficial in the treatment of various diseases because of less side effects, safety and biocompatibility. Therefore, the public and market demand is so high. That's why many medicinal plants are facing serious threats either extinction or loss of genetic diversity [9]. Several plants show good antioxidant activity [10].

\section{Material and Methods}

\section{Plant Collection and Authentication}

Seeds and plant specimen of Phytolacca latbenia (Moq.) Walte were collected from Neelum valley Azad Kashmir in September 2018 and plant was identified with the help of available literature flora of Pakistan [11]. Voucher specimen was deposited at (KUH) Karachi University Herbarium, Centre for Plant Conservation, University of Karachi.

\section{Extraction from Seeds}

Extraction: Powder of Phytolacca Latbenia seeds (10g) was taken in $200 \mathrm{ml}$ of 4 different solvents Acetone, chloroform, 
methanol and water in each conical flask, and then kept on a shaker for $48 \mathrm{~h}$. After $48 \mathrm{~h}$, the mixture was filtered through filter paper (whattman no 1) then dried. Powder of extract was used for further tests.

Physicochemical Analysis: Extractive values, ash values, under various solvents, acid and water solubility percentage were checked as described by Esha et al. [12].

\section{Qualitative Phytochemical Screening}

Alkaloids and were analyzed by Evans method [13], proteins by Million's method [14,15]. Carbohydrates by Benedict's test [16], Phenolic compounds by Ferric chloride test [17], Lead acetate test [18], Flavonoids by [18], Glycosids by Borentrager's test [18], Fixed oil by Spot test [19], Terpenoids by [20], Saponin by Foam test [19].

\section{Results and Discussion}

\section{Discussion}

Phytolacca latbenia (Moq.) Walte found in India, China and Japan in Pakistan it is found in Hamaliya region from 1500$3000 \mathrm{~m}$. Root contains a phytolaccin compound which is used in medicine and poisonous as well [11] root is customarily used as a medicine against antibacterial, antiasthmatic, antitussive, antidote, antifungal, expectorant, laxative, diuretic, and vermifuge whole plant is toxic, this remedy should be used with prudence and preferably under the supervision of a qualified practitioner [21]. The plant has fascinating chemistry useful against anti-AIDS drug and potent anti-inflammatory agents, antiviral proteins and other substances that affect cell division [22]. The leaves and twigs have a narcotic effect and used as a sedative to convince sleep. Root oil used for joint pain [23].

Table 2: Qualitative Phytochemical screening of seeds of Phytolacca latbenia in different solvent.

\begin{tabular}{|c|c|c|c|c|c|}
\hline S.NO & Phytochemical Test & Acetone & Chloroform & Methanol & Water \\
\hline \multirow{3}{*}{1} & Alkaloid & & & & \\
\hline & Wagner's Reagent & - & - & - & ++ \\
\hline & Mayer's Reagent & - & - & - & ++ \\
\hline \multirow{2}{*}{2} & Carbohydrate & & & & \\
\hline & Benedict's Test & + & + & + & + \\
\hline \multirow{3}{*}{3} & Protein and amino acid & & & & \\
\hline & Biuret Test & - & - & - & - \\
\hline & Millions Test & ++ & ++ & ++ & ++ \\
\hline \multirow{3}{*}{4} & Phenolic compounds & & & & \\
\hline & Lead Acetate & + & + & + & ++ \\
\hline & Ferric Chloride Test & + & + & + & ++ \\
\hline 5 & Flavonoids & - & - & + & + \\
\hline \multirow{2}{*}{6} & Glycoside & & & & \\
\hline & Borntrager's Test & - & - & - & - \\
\hline \multirow{2}{*}{7} & Fixed Oil & & & & \\
\hline & Spot Test & + & + & + & + \\
\hline
\end{tabular}

Table 1: Physicochemical analysis of seeds of Phytolacca latbenia (Moq.) Walte.

\begin{tabular}{|c|c|c|}
\hline $\mathbf{1}$ & Physical State of Ash & Fine powder \\
\hline 2 & Colour of ash & Black \\
\hline 3 & \% of loss on drying & $31.60 \%$ \\
\hline 4 & \% of ash content & $22.46 \%$ \\
\hline 5 & Water soluble ash & $27 \%$ \\
\hline 6 & Water insoluble ash & $73 \%$ \\
\hline 7 & Acid soluble ash & $37 \%$ \\
\hline 8 & Acid insoluble ash & $67 \%$ \\
\hline 9 & Acetone soluble extractive value & $12 \%$ \\
\hline 10 & Chloroform soluble extractive value & $6 \%$ \\
\hline 11 & Methanol soluble extractive value & $10 \%$ \\
\hline 12 & Water soluble extractive value & $40 \%$ \\
\hline
\end{tabular}

Seeds of Phytolacca latbenia (Moq.) Walte were examined physicchemically and phytochemically. Our results revealed that seeds of Phytolacca latbenia (Moq.) Walte is rich in various bioactive compounds when using different solvents such as acetone, chloroform, methanol, and water. The results of the phytochemical screening of phytolacca latbeniaic seeds shown in table 2 physicochemical results table 1 . Majority of compound detected only in water extract such as alkaloid, Carbohydrates, protein, phenolic compounds, flavonoids, fixed oil, saponin and terpenoids as well. These compounds were absent in acetone, chloroform and methanol extracts In Borntrager's test glycosides was absent. The high extractive value was in water solvent $40 \%$ it was lower in chloroform solvent $6 \%$. The ideal solvent for the extraction of seeds of Phytolacca latbenia (Moq.) Walte is water, in which best results were achieved [24-28] (Tables 1-2). 


\begin{tabular}{|c|c|c|c|c|}
\hline 8 & Terpenoids & + & + & + \\
\hline 9 & Saponin & & & + \\
\hline & Foam Test & - & - & ++ \\
\hline
\end{tabular}

Key: += present, - = absent, ++ =present in moderate amount, +++=present in high amount.

\section{Conclusion}

Phytolacca latbenia (Moq.) Walte produce huge amount of seeds and show therapeutic potential due to the presence of various phytochemical.

\section{Acknowledgment}

We are grateful to Higher Education Commission for providing grant for this research under Project 20-3847/NRUP/R\&D/ HEC/14.

\section{References}

1. Flatlandsmo K (2010) Documentation of beneficial effects of bioactive plant compounds in food and feed In: Bioactive compounds in plants benefits and risks for man and animals Aksel Bernhoft editor Oslo: The Norwegian Academy of Science and Letters, Norway.

2. Ivanova D, Gerova D, Chervenkov Tand Yankova T (2005) Polyphenols and antioxidant capacity of Bulgarian medicinal plants. J Ethnopharmacol 96: 145-150.

3. Shrikumar S, Ravi TK (2007) Approaches towards development and promotion of herbal drugs. Pharmacogn Rev 1: 180-184.

4. Mandal V, Mohan Y, Hemalatha S (2007) Microwave assisted extraction: An innovative and promising extraction tool for medicinal plant research. Pharmacogn Rev 1: 7-18.

5. Hertog MGL, Feskens EJM, Kromhout D, Hollman PCH, et al. (1993) Dietary antioxidant flavonoids and risk of coronary heart disease: The Zutphen elderly study. Lancet 342: 1007-1011.

6. Han X T, Shen, Lou H (2007) Dietary polyphenols and their biological significance. Int J Mol Sci 8: 950-988.

7. Jana S, Shekhawat GS (2010) Phytochemical analysis and antibacterial screening of in vivo and in vitro extracts of Indian medicinal herb: Anethum graveolens. Res J Med Plant 4: 206-212.

8. Cowan MM (1999) Plant products as antimicrobial agents. Clin Microbiol 12: 564-582.

9. Misra A (2009) Studies on biochemical and physiological aspects in relation to phyto-medicinal qualities and efficacy of the active ingredients during the handling, cultivation and harvesting of the medicinal plants. J Med Plants Res 3: 1140-1146.

10. Brighente IMC, Dias M, Verdi LG, Pizzolatti MG (2007) Antioxidant activity and total phenolic content of some Brazilian species. Pharm Biol 45: 156-161.

11. Nasir E, Ali SI (1971-1994) Flora of Pakistan. Ali SI and Qasir M (Eds) National Herbarium, PARC, Islamabad and Department of Botany Uni- versity of Karaci, Pakistan.

12. Esha V, Shilpa C , Bharat P, Neeru (2016) Physico-Chemical and Phytochemical Evaluation of Dendrobium macraei Lindl. (Whole Plant). International Journal of Pharmacognosy and Phytochemical Research 8(11): 1801-1811.

13. Evans WC (1997) Trease and Evans pharmacognosy, $14^{\text {th }}$ edn Harcourt Brace and company. Asia Pvt Ltd, Singapore.

14. Rasch E, Swwift F (1960) Micro Photometric analysisnmof the cytochemical million reactions. J Histochem Cytochem 8: 4-17.

15. Ghan PB (1984) Plant Histochemistry and cytochemistry: An Introduction. Academic press, Florida, USA.

16. Ramakrishnan S, Prasanan KG Rajin R (1994) Textbook of medicinal biochemistry. Orient Longman, New Delhi, India.

17. Mace ME (1963) Histochemical Localization of phenols in healthy and diseased Banana roots. Phytopathology 16: 915-925.

18. Raaman N (2006) Phytochemical Techniques, New India Publishing Aegency Pitam Pura, New Delhi.

19. Kokate CK (1999) Practical Pharmacognosy, $4^{\text {th }}$ edn Vallabh Prakashan Publicatin, New Delhi, India.

20. Ajayi I A, Ajibade 0, Oderinde R A (2011) Preliminary Phytochemical Analysis of some Plant Seeds. Res J Chem Sci 1(3).

21. Duke J A, Ayensu E S (1985) Medicinal Plants of China.

22. Bown D (1995) Encyclopaedia of Herbs and their Uses. Dorling Kindersley, Herb gardening, London, p. 424.

23. Kumar M, Paul Y, Anand V K (2009) An Ethnobotanical Study of Medicinal Plants used by the Locals in Kishtwar, Jammu and Kashmir India. Ethnobotanical Leaflets 13: 1240-56

24. Askari SH, Abid (2010) Poisonous plants of Pakistan textbook published by Ameena Saiyid, oxford university Press, UK.

25. Anonymous (2001) IUCN Red List Categories and Criteria: Version 3.1 IUCN Species Survival Commission. IUCN, Gland, Switzerland and Cambridge, UK.

26. Shinwari ZK, Watanabe T, Rehman M, Yoshikawa T (2006) A pictorial guide to medicinal plants of Pakistan Published by kohat university of science and technology Kohat, Pakistan.

27. Srivastava N, SharmaV, Kamal, Dobriyal BAK, Jadon V S (2010) Advanced in Research on Aconitumso.(Ranunculaceae) under different area: A Review Biotechnology.

28. Wagner $H$ (1993) Pharmazeutische Biologic $5^{\text {th }}$ edn, Gustav fisher Vwelag, Stuttgart, Germany. 




BY DOI: 10.19080/OMCIJ.2019.09.555754
Your next submission with Juniper Publishers will reach you the below assets

- Quality Editorial service

- Swift Peer Review

- Reprints availability

- E-prints Service

- Manuscript Podcast for convenient understanding

- Global attainment for your research

- Manuscript accessibility in different formats

( Pdf, E-pub, Full Text, Audio)

- Unceasing customer service

Track the below URL for one-step submission https://juniperpublishers.com/online-submission.php 